\title{
Introduction: 25th Dubrovnik Economic Conference Symposium
}

\author{
Paul Wachtel ${ }^{1} \cdot$ Boris Vujčić ${ }^{2}$ \\ Published online: 19 May 2020 \\ (c) Association for Comparative Economic Studies 2020
}

The Croatian National Bank marked a quarter century of distinguished conferences with the 25th Dubrovnik Economic Conference (DEC) which was held on June 14-16, 2019. Starting in 1994 as the Dubrovnik Conference on Transition Economics, the conferences have a deserved reputation for quality research on the changing world economy and serious policy discussions. We are pleased to present here four papers from the conference which have been reviewed and revised for publication.

Croatian National Bank conferences have a well-established reputation for the presentation of excellent research on the changing world economy, and we are pleased to publish these papers. We are grateful for comments provided by the discussants in Dubrovnik, Iain Begg, Nauro Campos, Randall Filer, Tomislav Ridzak, as well as by our anonymous referees.

The program committee for the 25th Dubrovnik Economic Conference was chaired by Dr. Boris Vujčić, Governor of the Croatian National Bank. The other committee members were Paul Wachtel, Professor of Economics at the Leonard N. Stern School of Business at New York University, Randall K. Filer, Professor of Economics at Hunter College of the City University of New York, and at CERGEEI, Prague and Dr. Dubravko Mihaljek, Head of Macroeconomic Analysis, Bank for International Settlements. The selection committee for the Young Economists' Seminar which is held in conjunction with DEC consisted of Professors Randall K. Filer, Evan Kraft, American University, Oleh Havrylyshyn, Carleton University, and Paul Wachtel.

In addition to the papers published here, Michael Waugh, J. Peter Neary, Paul Wachtel and Mario I. Blejer presented papers in Dubrovnik. These papers can be

Paul Wachtel

Pwachtel@stern.nyu.edu

Boris Vujčić

bvujcic@hnb.hr

1 Stern School of Business, New York University, 44 West 4th Street, New York, NY 10012-1126, USA

2 Croatian National Bank, Trg hrvatskih velikana 3, 10002 Zagreb, Croatia 
found at the Croatian National Bank web site: https://www.hnb.hr/-/the-25th-dubro vnik-economic-conference.

Finally, the success of the Dubrovnik Economic Conference owes much to the efforts of Tomislav Presečan, Chief Operating Officer and the entire staff of the Croatian National Bank.

Publisher's Note Springer Nature remains neutral with regard to jurisdictional claims in published maps and institutional affiliations. 